\title{
PENERAPAN STRATEGI PEMBELAJARAN INKUIRI UNTUK MENINGKATKAN AKTIVITAS DAN HASIL BELAJAR BIOLOGI SISWA KELAS XII IPA 2 SMAN 1 MAKASSAR (Studi pada Materi Pertumbuhan dan Perkembangan Tumbuhan)
}

\author{
Nurhikma Ramadhana \\ Jurusan Pendidikan Biologi FMIPA Universitas Sulawesi Barat \\ e-mail: ramabiologi@gmail.com
}

\begin{abstract}
ABSTRAK
Penurunan Kualitas pendidikan di Indonesia mengajak kita untuk meninjau kembali mengenai aspek pendukung peningkatan kualitas pendidikan Indonesia. Salah satu diantaranya adalah kualitas pengelolaan pendidikan, dimana guru memiliki peran aktif dalam mengamati dan mengawasi setiap permasalahan yang terdapat di dalam kelasnya. Guru dituntut untuk senantiasa meneliti setiap tindakan yang diberikan terhadap masalah-masalah yang terjadi di dalam kelas (Classroom Action Research). Tujuan penelitian ini yaitu untuk meningkatkan aktivitas dan hasil belajar siswa. Salah satu tindakan yang diberikan yaitu dengan menerapkan strategi pembelajaran inkuiri untuk mengaktifkan siswa dalam proses pembelajaran. Aktivitas siswa diamati dan dianalisis secara kuantitatif dan kualitatif dengan mengisi lembar observasi, yang mengacu pada sintaks inkuiri yaitu, tahap orientasi, perumusan masalah, perumusan hipotesis, pengumpulan data, pengujian hipotesis, penarikan kesimpulan. Sedangkan untuk hasil belajar siswa dengan pemberian evaluasi hasil belajar disetiap siklus, kemudian dianalisis secara kuantitatif. Hasil penelitian menunjukkan bahwa pada terjadi peningkatan aktivitas di setiap sintaks dalam strategi pembelajaran inkuiri. Selain itu, untuk hasil belajar ditemukan bahwa pada Siklus I nilai rata-rata siswa yaitu 52,29 dari nilai ideal 100, dengan frekuensi siswa yang mencapai nilai baik sekali sangat rendah yaitu $0 \%$ atau tidak ada dari jumlah siswa sebesar 41 orang siswa. 9,76\% atau 4 orang siswa termasuk dalam kategori baik, 41,46\% atau 17 orang siswa dalam kategori cukup, 34,15\% atau 14 orang siswa dalam kategori kurang dan 14,63\% atau 6 orang siswa berada dalam kategori gagal. Sedangkan untuk Siklus II nilai rata-rata siswa yaitu 64,88 dari nilai ideal 100, dengan Frekuensi siswa yang memperoleh nilai pada kategori baik sekali sebanyak 2 orang siswa atau 4,88\%, sementara, 39,02\% atau 16 orang siswa termasuk dalam kategori baik, 48,78\% siswa dalam kategori cukup, 7,32\% atau 3 orang siswa yang berada pada kategori kurang dan 0\% yang berada pada kategori gagal. Berdasarkan hasil analisis secara kuantitatif peningkatan hasil belajar biologi siswa dari Siklus I ke Siklus II sebesar 12,59\%. Berdasarkan hasil penelitian, maka disimpulkan bahwa terjadi peningkatan aktivitas dan hasil belajar biologi siswa kelas XII IPA 2 SMA Negeri 1 Makassar. Dalam penerapan strategi pembelajaran inkuiri, disarankan untuk meluangkan waktu yang lebih banyak dan memberikan kebebasan kepada siswa untuk lebih berkreasi terhadap materi pelajaran yang diberikan.

Keywords: Pembelajaran Inkuiri, Hasil belajar biologi
\end{abstract}

\section{A. Latar Belakang Masalah}

\section{PENDAHULUAN}

Upaya peningkatan kualitas manusia Indonesia tidak terlepas dari peran serta para pendidik dalam proses peningkatan hasil belajar siswa, yang tidak hanya mengacu pada aspek kognitif akan tetapi juga dari segi afektif dan motorik. Berbagai upaya dilakukan diantaranya perbaikan kurikulum serta menerapkan berbagai strategi dan metode pembelajaran yang efektif dalam mengajarkan suatu materi pelajaran.

Hasil belajar merupakan salah satu tujuan dari pembelajaran. Akan tetapi, perlu disadari bahwa salah satu faktor yang sangat mempengaruhi hasil belajar tersebut adalah bagaimana siswa melakukan proses untuk mencapai hasil belajar sebaik-baiknya. Sehingga ketika guru mendapatkan masalah di dalam kelas, terutama dalam hal kekurangaktifan siswa dalam kegiatan pembelajaran maka sebaiknya guru menyelidiki kemungkinan penyebab kekurangaktifan tersebut. Tidak hanya itu, masalah yang terjadi di dalam kelas dapat pula di tanyakan langsung kepada subjek belajar atau siswa itu sendiri. 
Hasil observasi yang telah ditemukan di SMAN 1 Makassar khusunya kelas XI IPA, ditemukan bahwa guru mengeluhkan akan keaktifan dari siswa yang semakin menurun. Disisi lain, hasil observasi yang dilakukan kepada siswa dengan membagikan angket yang berisi serangkaian pertanyaan mengenai tanggapan mereka akan proses pembelajaran biologi yang selama ini diberikan oleh guru, ditemukan bahwa terdapat kejenuhan akan metode mengajar guru yang sifatnya monoton, yaitu dengan berceramah. Siswa sangat jarang diberikan kegiatan praktikum baik yang dirancang sendiri oleh guru ataupun oleh siswa, sehingga sebagian besar siswa tidak begitu memperdulikan guru ketika proses pembelajaran berlangsung.

Sementara dalam proses pembelajaran siswa, terdapat dua aspek yang terlibat yaitu, guru sebagai pendidik dan siswa sebagai peserta didik. Guru dalam hal ini tidak lagi menjadi subjek utama pentransfer ilmu atau sumber ilmu, akan tetapi siswalah yang diharapkan menjadi pelaku utama dalam kegiatan pembelajaran. Guru hanya sebagai fasilitator dan mediator ketika siswa mengalami kesulitan dalam proses pembelajaran.

Penerapan strategi pembelajaran inkuiri sebagai salah satu langkah yang dapat ditempuh sebagai suatu strategi pembelajaran yang didalamnya menuntut keaktifan siswa dalam pembelajaran, atau pusat pembelajaran berada di tangan siswa (student centre approach). Dalam strategi pembelajaran inkuiri, siswa dibimbing untuk menemukan hal-hal baru berdasarkan permasalahan yang ada baik yang diberikan oleh guru maupun yang ditimbulkannya sendiri dengan mengacu kepada langkah-langkah ilmiah, yang berupa pengalaman, perumusan masalah, memperkirakan jawaban (berhipotesis), mengumpulkan data-data, pengujian hipotesis dan penarikan kesimpulan. Langkah-langkah ini akan membawa siswa untuk belajar tidak hanya sekedar menghapal dan mengetahui sesuatu akan tetapi lebih kepada memahami dan lebih bersikap ilmiah terhadap apa yang ditemukan dalam lingkungannya. Dengan demikian, diharapkan siswa benar-benar mengerti inti dari pelajaran yang diajarkan, sehingga secara tidak langsung sebagai jalan menuju pencapaian hasil belajar yang maksimal.

\subsection{Waktu dan Tempat Penelitian}

\section{METODE PENELITIAN}

Penelitian ini dilaksaakan pada bulan Juli sampai Agustus 2014, di SMAN 1 Makassar. Subjek penelitian adalah siswa kelas XII IPA 2 SMAN 1 Makassar.

\subsection{Prosedur Penelitian}

Penelitian ini merupakan penelitian tindakan kelas (Classroom Action Research) yang terdiri atas dua siklus. Pada masing-masing siklus terdiri atas tahap perencanaan tindakan, tahap pelaksanaan, tahap observasi dan evaluasi, serta tahap refleksi. Untuk Siklus I dilaksanakan sebanyak 3 kali pertemuan, sedangkan Siklus II dilaksanakan sebanyak 4 kali pertemuan.

\subsection{Teknik Pengumpulan Data}

Data tentang aktivitas pembelajaran selama tindakan dilakukan, diambil dengan menggunakan lembar observasi. Pada proses pengisian lembar observasi, semua indikator dari aktivitas yang diamati tercantum didalamnya. Jika siswa melakukan setiap aktivitas yang menjadi tolok ukur, maka ia akan memperoleh tanda checklist $(\sqrt{ })$ pada lembar observasi. Keadaan yang diobservasi adalah kegiatan siswa dalam proses pembelajaran inkuiri. Sedangkan untuk data mengenai nilai hasil belajar diperoleh dari tes hasil belajar setiap akhir siklus.

\subsection{Hasil Penelitian}

\section{HASIL DAN PEMBAHASAN}

Penelitian ini mengacu kepada segala aktivitas yang dituntut dalam strategi pembelajaran inkuiri yang dijalankan oleh siswa selama proses pembelajaran berlangsung serta hasil belajar yang diperoleh dari siklus I dan II.

\section{a. Siklus I}

\section{(i) Aktivitas}

Pada tahapan orientasi atau pengenalan materi ajar, hasil observasi menunjukkan bahwa jumlah siswa yang turut berpartisipasi dalam kegiatan tanya jawab dengan guru hanya dua orang, sedangkan yang serius mendengarkan dan menulis indicator atau tujuan pembelajaran yang akan diajarkan hanya dua puluh dua orang. Secara keseluruhan, dari 41 jumlah siswa kelas XII IPA 2 terdapat 29 siswa yang tidak melakukan keributan di dalam kelas, dan tercatat 3 orang siswa yang tidak hadir, 
selebihnya 9 orang siswa ribut atau tidak memperhatikan guru pada saat proses pembelajaran berlangsung.

Tahap kedua yaitu tahap merumuskan masalah. Pada tahap ini, respon siswa cukup rendah, baik ketika memberikan tanggapan atas pertanyaan yang diajukan oleh guru maupun mengutarakan pendapatnya dalam memberikan rumusan masalah ketika kegiatan diskusi berlangsung di masingmasing kelompok, yaitu hanya sekitar 10 orang. Sedangkan pada tahap perumusan hipotesis jumlah siswa yang mampu memberikan rumusan hipotesis frekuensinya cukup rendah yaitu 17 orang siswa.

Pada tahap pengumpulan data dalam hal ini dilakukan dengan kegiatan praktikum, sebagian besar siswa nampak aktif termasuk membawa alat dan bahan sendiri sesuai dengan rancangan percobaan yang telah dibuat pada pertemuan yang lalu. Rata-rata keaktifan siswa dalam tahap ini cukup rendah, yaitu dari delapan item aktivitas yang diamati, rata-rata siswa yang aktif hanya 17 orang. Sementara dalam tahap pengujian hipotesis yang berlangsung dalam suasana diskusi, rata-rata siswa yang aktif hanya 8 orang. Sedangkan untuk aktifitas penarikan kesimpulan rata-rata siswa yang aktif hanya 9 orang.

(ii) Hasil Belajar

Data hasil belajar siswa siklus I diperoleh melalui evaluasi hasil belajar yang dilaksanakan setelah akhir siklus I. Adapun distribusi, frekuensi dan persentase hasil belajar biologi siswa dapat dilihat pada Tabel 1 berikut:

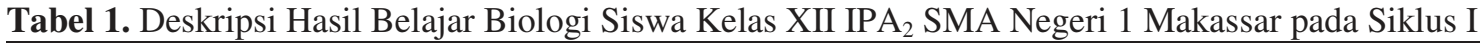

\begin{tabular}{|c|l|c|c|}
\hline Interval Nilai & \multicolumn{1}{|c|}{ Kualifikasi } & Frekuensi & $\begin{array}{c}\text { Persentase } \\
(\%)\end{array}$ \\
\hline $80-100$ & Baik sekali & 0 & 0 \\
$66-79$ & Baik & 4 & 9,76 \\
$56-65$ & Cukup & 17 & 41,46 \\
$40-55$ & Kurang & 14 & 34,15 \\
$30-39$ & Gagal & 6 & 14,63 \\
\hline \multicolumn{2}{|r|}{ Jumlah } & 41 & 100 \\
\hline
\end{tabular}

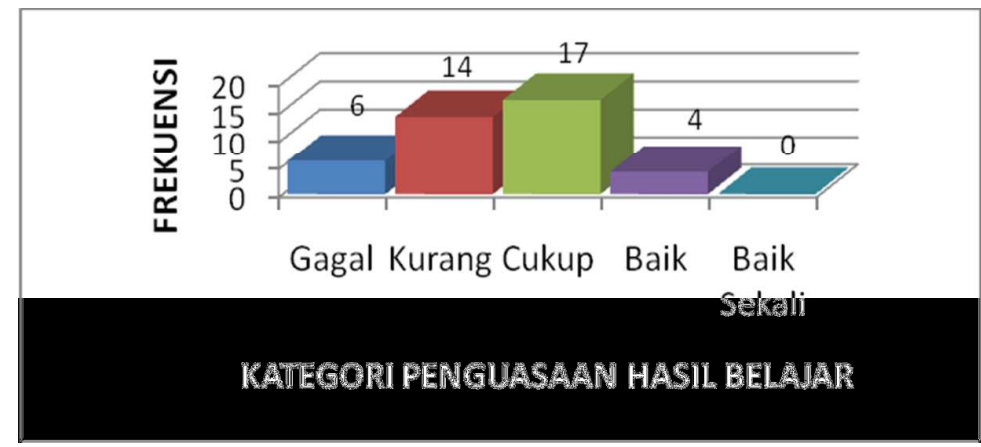

Gambar 1. Diagram batang persentase hasil belajar Biologi siswa kelas XII IPA 2

Tabel 1 menunjukkan bahwa secara individu 0\% tidak ada siswa termasuk dalam kategori baik sekali, $9,76 \%$ atau 4 orang siswa termasuk dalam kategori baik, $41,46 \%$ atau 17 orang siswa dalam kategori cukup, 34,15\% atau 14 orang siswa dalam kategori kurang dan 14,63\% atau 6 orang siswa berada dalam kategori gagal.

\section{b. Siklus II}

\section{(i). Aktivitas}

Hasil observasi aktifitas belajar siswa Kelas XII IPA 2 SMA Negeri 1 Makassar, maka secara umum respon dalam proses pembelajaran di siklus II sudah cukup baik. Untuk tahap orientasi ratarata frekuensi siswa yang melakukan aktivitas sebanyak 22 orang siswa, pada tahap perumusan masalah rata-rata frekuensi sebanyak 20 orang, perumusan hipotesis sebanyak 19 orang, tahap 
pengumpulan data 25 orang siswa, tahap pengujian hipotesis sebesar 14 orang sedangkan untuk tahap penarikan kesimpulan rata-rata frekuensi siswa yang melakukan aktivitas sebanyak 17 orang.

\section{(ii). Hasil Belajar}

Data hasil belajar siswa siklus II diperoleh melalui evaluasi hasil belajar yang dilaksanakan setelah akhir siklus II. Adapun distribusi, frekuensi dan persentase hasil belajar biologi siswa dapat dilihat pada Tabel 2 berikut:

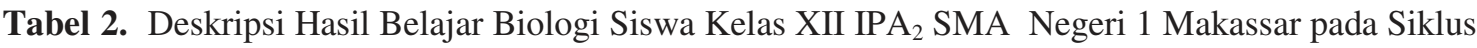
II

\begin{tabular}{|c|l|c|c|}
\hline Interval Nilai & \multicolumn{1}{|c|}{ Kualifikasi } & Frekuensi & Persentase (\%) \\
\hline $80-100$ & Baik sekali & 2 & 4,88 \\
$66-79$ & Baik & 16 & 39,02 \\
$56-65$ & Cukup & 20 & 48,78 \\
$40-55$ & Kurang & 3 & 7,32 \\
$30-39$ & Gagal & 0 & 0 \\
\hline \multicolumn{2}{|c|}{ Jumlah } & 41 & 100 \\
\hline
\end{tabular}

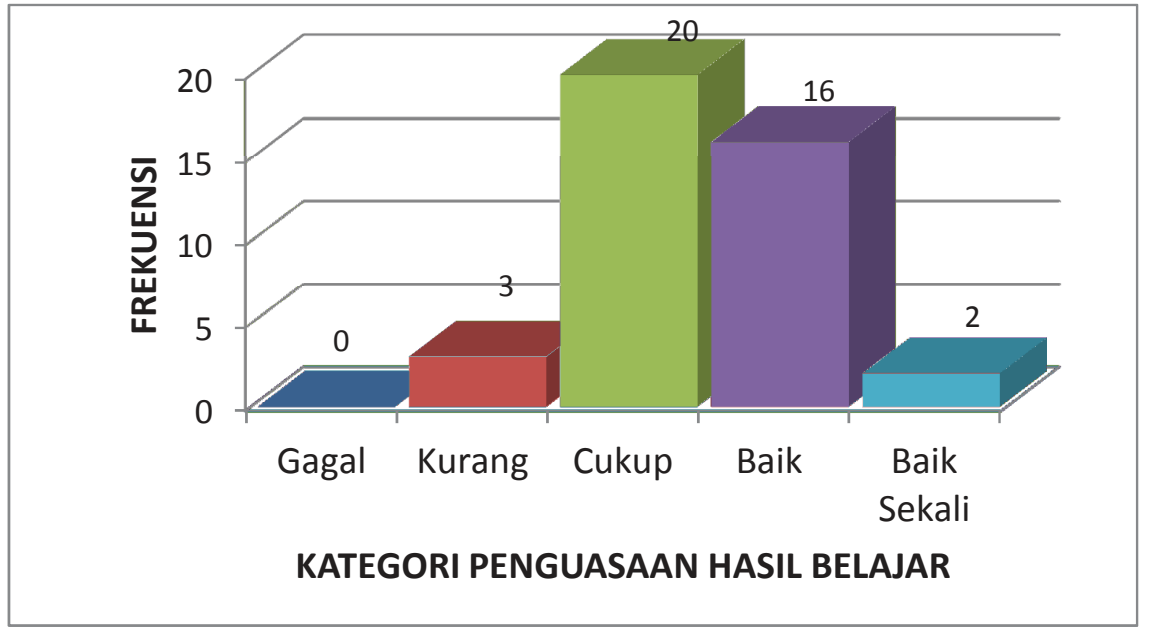

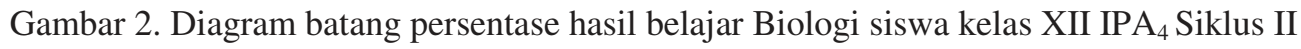

Tabel 2 menunjukkan bahwa secara individu 4,88\% atau 2 orang siswa termasuk dalam kategori baik sekali, 39,02\% atau 16 orang siswa termasuk dalam kategori baik, 48,78\% siswa dalam kategori cukup, 7,32\% atau 3 orang siswa yang berada pada kategori kurang dan $0 \%$ yang berada pada kategori gagal. Hal ini menunjukkan bahwa dari hasil penelitian yang dilakukan, dari siklus I terdapat peningkatan aktivitas pada siklus II.

\subsection{Pembahasan}

Berdasarkan hasil analisis kuantitatif dari lembar observasi aktifitas siswa, dimana pada siklus II para siswa telah memperlihatkan aktifitasnya yang lebih baik selama kegiatan pembelajaran. Para siswa telah dapat melakukan komunikasi dengan baik dengan teman kelompoknya untuk memahami suatu permasalahan dalam materi pelajaran sekaligus merancang percobaan untuk membuktikannya. Sehingga dengan demikian, para siswa mampu untuk memahami pelajaran karena sebagian besar kegiatan pembelajaran berasal dari mereka sendiri.

Membandingkan antara aktivitas pada siklus I dengan siklus II, maka terdapat beberapa item yang diamati yang memperlihatkan rata-rata frekuensi siswa yang melakukan aktifitas dimana signifikansi perubahan jumlahnya kecil. Misalnya pada item interaksi siswa dengan pengajar tahap 
orientasi ataupun perumusan masalah, item yang menuntut siswa untuk mampu bertanya, menanggapi, mempertahankan jawaban ataupun menunjukkan hasil pengamatan yang telah diperoleh perubahan frekuensinya kecil, akan tetapi nampak bahwa siswa yang melakukan aktivitas pada itemitem tersebut di siklus II, sebagian besar adalah siswa yang tidak melakukan aktivitas tersebut pada siklus I, sehingga diketahui bahwa para siswa mulai mampu untuk berinteraksi dan meningkatkan aktivitasnya dalam kegiatan pembelajaran. Atau dengan kata lain adanya suara baru dalam kegiatan pembelajaran pada siklus II. Sementara untuk nilai hasil belajar biologi siswa Kelas XII IPA 2 dari terjadi peningkatan Siklus I ke Siklus II sebesar 12,59\%.

Hasil penelitian menunjukkan bahwa terjadinya peningkatan aktivitas belajar siswa dan juga dari segi nilai hasil belajar yang diperoleh dari Siklus I ke Siklus II. Hal ini sesuai dengan kerucut Edgar Dale yang digambarkan oleh Sanjaya (166:2008), yang dijelaskan bahwa dalam pembelajaran dengan memberikan pengalaman langsung bagi para siswa, maka ada kecenderungan hasil yang diperoleh siswa menjadi kongkrit sehingga akan memiliki ketepatan yang tinggi.

Proses pembelajaran yang berlangsung dengan menerapkan strategi pembelajaran inkuiri menunjukkan hasil yang optimal, dimana siswa telah mampu menjawab sendiri permasalahan yang diajukan. Hasil penelitian menunjukkan bawa dengan melakukan kegiatan eksperimen oleh siswa untuk membuktikan sesuatu, maka materi pelajaran dengan mudah dapat difahami oleh siswa. Hal ini seperti dituliskan oleh Mestre dan Cocking (2002, dalam Ibrahim, 2009) bahwa pada proses inkuiri, pebelajar termotivasi untuk terlibat langsung atau berperan aktif secara fisik dan mental dalam kegiatan belajar, dimana dalam lingkungan kelas nampak aktifitas yang didominasi oleh siswa sementara guru berperan sebagai fasilitator pembelajaran yang membantu tercapainya kompetensi dan tujuan pembelajaran.

\subsection{Kesimpulan}

\section{KESIMPULAN}

Berdasarkan hasil penelitian dan pembahasan yang telah dikemukakan, maka dapat ditarik kesimpulan sebagai berikut :

1. Aktifitas dalam proses pembelajaran biologi pada siswa Kelas XII IPA 2 SMA Negeri 1 Makassar setelah diterapkannya strategi pembelajaran inkuiri menunjukan adanya peningkatan disetiap sintaks inkuiri yang diamati sesuai dengan petunjuk lembar observasi dan dianalisis secara kualitatif.

2. Melalui penerapan strategi pembelajaran inkuiri hasil belajar biologi siswa kelas XII IPA 2 SMA Negeri 1 Makassar meningkat dari siklus I ke siklus II, yaitu Siklus I dengan rata-rata perolehan nilai sebesar 52,29 sedangkan pada Siklus II yaitu 64,88. Peningkatan hasil belajar yang diperoleh dari Siklus I ke Siklus II yaitu sebesar 12,59\%. Dan terjadi peningkatan persentase frekuensi siswa yang memiliki nilai hasil belajar dalam kategori baik sekali yaitu dari $0 \%$ menjadi $4,88 \%$, sementara untuk kategori gagal terjadi penurunan yaitu dari $14,63 \%$ menjadi $0 \%$ di siklus II.

\subsection{Saran}

Berdasarkan hasil penelitian dapat disimpulkan bahwa strategi pembelajaran inkuiri dapat disajikan sebagai satu alternatif strategi dalam melaksanakan pembelajaran biologi di sekolah. Dalam penerapan strategi pembelajaran inkuiri, disarankan untuk meluangkan waktu yang lebih banyak dan memberikan kebebasan kepada siswa untuk lebih berkreasi terhadap materi pelajaran yang diberikan.

\section{Daftar Pustaka}

Anonim. 2006. Peranan PPG dalam Memfasilitasi Peningkatan Mutu Pendidikan dan Tenaga Kependidikan dalam Upaya Meningkatkan Mutu Pendidikan. http://www.pmptk.net/file. Diakeses pada tanggal 1 Februari 2013.

Arikunto, S. 2006. Prosedur Penelitian Suatu Pendekatan Praktik. Rineka Cipta. Jakarta.

Arikunto, S, Suharjono, Supardi. 2008. Penelitian Tindakan Kelas. Bumi Aksara. Jakarta. Aryulina, Muslimin, Manaf, Widi. 2008. Biologi SMA 3 untuk Kelas XII. Esis Erlangga .Jakarta. Campbell, Reece, Mitchell. 2003. Biologi Jilid II. Erlangga. Jakarta. Depdiknas. 1995. Pengantar Pendidikan. Rineka Cipta. Jakarta. 
Haling, Parumbuan, Pattaufi, Arsal, Arnidah, Faridah. 2007. Belajar dan Pembelajaran. Badan Penerbit UNM. Makassar.

Hamalik. 2004. Proses Belajar Mengajar. Bumi Aksara. Jakarta.

Ibrahim, M. 2009. Pembelajaran Inkuiri. http://www.SekolahBerkualitas,Solusi BangsaPembelajaranInkuiri.htm. Diakses pada tanggal 10 Mei 2013.

Ismail. 2006. Fisiologi Tumbuhan. Jurusan Biologi FMIPA UNM. Makassar.

Kunandar. 2007. Implementasi KTSP dan Persiapan Menghadapi Sertifikasi Guru. PT Raja Grafindo Persada. Jakarta.

Nurhayati, B. dan L.W. Sappe. 2004. Strategi Belajar Mengajar. UNM. Makassar.

Sagala. 2007. Konsep dan Makna Pembelajaran. CV. Alfabet. Bandung.

Sanjaya. 2008. Strategi Pembelajaran Berstandar Proses Pendidikan. Kencana Prenada media Group. Jakarta.

Samsitamiharja. 1993. Fisiologi Tumbuhan. Depdikbud. Jakarta.

Slameto. 2003. Belajar dan Faktor-faktor yang Mempengaruhinya. Rineka Cipta. Jakarta.

Sukardi, I Ketut. 2007. Supervisi Klinis Penjamin Mutu Pendidikan. http://lpmpjogja.diknas.go.id. Diakses pada tanggal 1 Februari 2013.

Suryosubroto. 2002. Proses Belajar Mengajar di Sekolah. Rineka Cipta. Jakarta.

Sutrisno. 2008. Pengaruh Metode pembelajaran Inkuiri dalam Belajar Sains terhadap Motivasi Belajar Siswa. http://www.metodeinkuiri.html. Diakses pada tanggal 10 Mei 2013.

Yusuf . 2007. Teori, Metode, dan Penemuan Ilmiah di dunia Informasi, Komunikasi, dan Kelembagaan Informasi, termasuk Perpustakaan. http://bdg.centrn.net.id. Diakses pada tanggal 13 Februari 2013. 